apparently held by Waddington in common with many others, that separation of the sexes in the diploid phase is essentially a reflection of gametic differentiation. They may be related developmentally in diœcious organisms, but this should not blind us to their wholly dissimilar genetical consequences. Gametic differentiation cannot of itself lead to regular outbreeding, as is well shown by Triticum and Pisum, where the two kinds of gametes are strikingly different but where self-fertilization is the rule. On the other hand, crossing between different individuals must always follow from diœeism. As Waddington, in the section of his book which I quoted, and in the previous sentence which I did not quote, relates outbreeding primarily to gametic differentiation and thence secondarily to separation of the sexes, I must disagree with him. Differentiation of the gametes has no place in the genetical relation between outbreeding and unisexuality.

K. Mather.

John Innes Horticultural Institution,

Mostyn Road,

Merton Park,

London, S.W.19.

\section{Moisture-Relation as a Determining Factor in the Transformation of the Basidia of Certain Polyporacex}

BASIDIA of many Polyporacer at the end of the rainy season and during intervals between two showers of rain have been observed to be gradually transformed into hyphal elongations with terminal spores that are exactly like basidiospores. Conversely, on the advent of rain in the middle of a dry season, the hyphal elongations soon become reconverted into regular basidia.

Such conversion has been reproduced under experimental conditions. When a piece of the fruit body of a thin and desiccated specimen was placed under the running water of a laboratory tap overnight, the hyphal elongations entirely disappeared from the pore-tubes and the majority of the pore-tubes developed mature basidia with sterigmata and spores. When a piece of the same fruit-body was stuck to the lid of a moist agar-plate and examined daily under the microscope, it was found that, as the water of condensation gradually disappeared from the plate in the course of three or four days and the plate became comparatively dry (the relative humidity becoming reduced to about 85 per cent), the pore-tubes displayed a development of a large number of clamped and elongated hyphæ with terminal spores and a few abnormal elongated narrower basidia. The experiment was repeated several times and sometimes in reverse order, and in each case the same result was obtained. Such experimental conversion was quite successful with thin and easily desiccated specimens of Polyporus, Polystictus, and Hexagonia. It did not succeed well with very thick specimens of Polyporus, Drdalea, Fomes, Trametes, Lenzites, etc., as it is known that all specimens cannot withstand desiccation to the same degree.

From the experiments described above it is concluded that it is mainly the water-relation which controls the transformation of basidia into hyphal elongations with clamp-connexions and terminal spores and vice versa. None of the previous workers
(Patouillard, Matruchot, and Heim) has correlated this change of form of basidia with the varying external conditions.

Details of the work will be published elsewhere.

Botanical Laboratory, S. R. Bose.

Carmichael Medical College,

Calcutta.

March 20.

\section{Urinary Excretion of Combined Ascorbic Acid in Pulmonary Tuberculosis}

IT has been shown before ${ }^{1}$ that several plant tissues contain ascorbic acid in a combined state (ascorbigen) besides free ascorbic acid. This substance has since been considerably concentrated from cabbage ${ }^{2}$. The presence of combined ascorbic acid in urine was observed by Scarborough and Stewart $^{3}$ and by ourselves ${ }^{4}$. Evidence has been presented from this laboratory ${ }^{5}$ which indicates that ascorbic acid may have a detoxicating action both in the normal system and also in the infected condition. Thus after the injection of diphtheria and tetanus toxins into guinea pigs, excretion of free ascorbic acid in the urine was found to be diminished, associated with an increase in the output of combined ascorbic acid. Abbasy, Hill and Harris ${ }^{6}$ also showed that in certain infected conditions the excretion of free ascorbic acid was decreased, but the fate of the disappearing ascorbic acid is unknown. We have recently been able to investigate the relative excretion of free ascorbic acid, dehydro-ascorbic acid and combined ascorbic acid of nine normal individuals and of sixteen patients suffering from acute pulmonary tuberculosis. The mean values are given below and are expressed in terms of ascorbic acid (mgm.) excreted during a 24-hour period.

\begin{tabular}{|l|c|c|c|c|c|}
\hline & $\begin{array}{c}\text { Free } \\
\text { ascorbic } \\
\text { acid }\end{array}$ & $\begin{array}{c}\text { Dehy- } \\
\text { dro- } \\
\text { ascorbic } \\
\text { acid }\end{array}$ & $\begin{array}{c}\text { Com- } \\
\text { bined } \\
\text { ascorbic } \\
\text { acid }\end{array}$ & $\begin{array}{c}\text { Total } \\
\text { ascorbic } \\
\text { acid }\end{array}$ & $\begin{array}{c}\text { Combined } \\
\text { ascorbic acid } \\
\text { as percentage } \\
\text { of the total }\end{array}$ \\
\hline $\begin{array}{l}\text { Tuberculous } \\
\text { Normal }\end{array}$ & $\begin{array}{r}5 \cdot 82 \\
44 \cdot 62\end{array}$ & $\begin{array}{c}3.52 \\
7 \cdot 41\end{array}$ & $\begin{array}{r}8 \cdot 11 \\
15 \cdot 93\end{array}$ & $\begin{array}{c}17 \cdot 45 \\
67 \cdot 96\end{array}$ & $\begin{array}{c}42 \cdot 24 \\
23 \cdot 82\end{array}$ \\
\hline
\end{tabular}

A statistical analysis of the detailed individual figures, kindly carried out by Mr. K. C. Basak, gave the following results :

$\begin{array}{llr}\text { Difference of mean rates } & =18.42 \\ \text { Standard error of difference } & =7.56 \\ t & = & 2.44\end{array}$

The probability of obtaining such values of $t$ by chance alone is less than five in a hundred. The proportion of combined ascorbic acid excreted is therefore significantly higher in tuberculous patients than in normal healthy individuals.

From these results it appears first that there is a large reduction in the urinary output of total ascorbic acid in tuberculosis, and secondly that in tuberculosis there is a tendency to a relatively greater excetion of combined ascorbic acid. Apart from the simple destruction of ascorbic acid in the infected condition owing to increased metabolism, this evidence appears to support the view that ascorbic acid probably functions as a detoxicating agent, combines with certain toxins or toxic metabolites produced in the infected condition and tries to eliminate them. 